\title{
A Nest for the Soul: The Trope of Solitude in Three Early Modern Discalced Carmelite Nun-Poets
}

\section{Un niu per a l'ànima: El trop de la soledat en tres monges poeteses del Carmel Descalç en el inicis de l'edat moderna}

\author{
STACEY SCHLAU \\ sschlau@wcupa.edu
}

West Chester University (USA)

\begin{abstract}
For early modern Discalced Carmelite nun-poets, solitude remains tied to the paradoxical equation of life to death and death to life so famously parsed by St. Teresa. This essay examines poems by María de San Alberto (1568-1640), Ana de la Trinidad (1577-1613), and Gregoria Francisca de Santa Teresa (1653-1736) exploring the possibilities of creating and maintaining solitude while embarked on a quest for mystical union. Outstanding practitioners of the Teresian poetic tradition, the Founding Mother's religious and literary example allowed them the freedom to communicate with their religious sisters and subsequent readers, and thereby establish religious community through writing.
\end{abstract}

Keywords: Discalced Carmelite, mystical, nun-poet, poetry, solitude, St. Teresa

Resum: Per a les monges poeteses carmelites descalces de la primera edat moderna, la soledat segueix estant vinculada a l'equació paradoxal de la vida a la mort i la mort a la vida tan reconegudament tractada per santa Teresa. Aquest assaig examina poemes de María de San Alberto (1568-1640), Ana de la Trinidad (1577-1613), i Gregoria Francisca de Santa Teresa (1653-1736) que exploren les possibilitats de creació i manteniment de la solitud mentre es va embarcar en una recerca d'unió mística. Seguidores destacades de la tradició poètica teresiana, la literatura i la religiositat de la mare fundadora assoleix en elles la llibertat de comunicar-se amb les seues germanes de religió i els lectors posteriors, i amb això s'estableix una comunitat religiosa a través de l'escriptura permesos.

Paraules clau: Carmel Descalç, mística, monges poeteses, poesia, solitud, santa Teresa 
Solitude has played an important role in Carmelite spirituality, and therefore in its texts. Whether understood as a conscious part of the ascetic road to union with the divinity - hermits' living in the desert; withdrawal through the consolation of contemplation, meditation, and internal prayer; as a structured part of daily routines and rules - or as the absence of God during the exile of life before death, it has remained a core concern of the Order. From its earliest days, solitude has continued to provide a means of facilitating prayer, contemplation, and mystical union. A contemporary Discalced Carmelite website states that Carmelite spirituality proposes silence and solitude as necessary prerequisites for prayer and contemplation. Silence refers not only to external noise but also to the stilling of one's internal noises. The condition for listening attentively to the voice of God, which can otherwise not be discerned, is silence. Solitude provides the opportunity for silence; it makes possible the state of being alone that is necessary for focusing more attentively on the Beloved. Solitude then is not primarily separation or isolation from others, but a place of privileged encounter with the Beloved. ${ }^{1}$ From its origins to the present day, then, the «Carmelite Order will never hesitate to recognize itself in the first hermit whom the Bible describes for us and to model its life on that of men vowed to the contemplation of divine things in silence and solitude» (de la Croix). Retreat and solitude are recommended in every constitution. That is why deserts will later appear in Carmelite religious practice, for without them Carmel lacks one of its essential elements. $^{2}$

For early modern Discalced Carmelite nun-poets, solitude remains tied to the paradoxical equation of life to death and death to life so famously parsed by St. Teresa («Vivo sin vivir en mí... muero porque no muero»). The unsurprising notion that one must find a space not inhabited by other human beings in order to achieve success in mystical practice becomes an integral part of their poetic praxis. Exploration of this motif requires recognizing the gendered voice used so effectively by the Founding Mother's spiritual daughters to assert and shape a new kind of ecstatic experience of oneness with the divinity, which allows for the paradoxical development of an autonomous self. Jesús Fernando Cáseda Teresa insists that:

\footnotetext{
...cierta impronta de literatura femenina marcada por la Santa teresiana explica el que entonces, más que antes, surgiera un conjunto de escritoras que cultivan con este estilo literario sobre todo la poesía. Poesía, por tanto, expresiva, en lucha constante con lo inefable, con el adjetivo que busca descifrar lo inaprehensible. (1996: 89)
}

In order to attempt to express the ineffable, the texts studied here all respond to the imperative of physical and psychic space addressed so often in St. Teresa of Ávila's writings, including in the Constitution and Rules she delineated for convents of the Order that she reformed.

1 http:/ /www.carmelite.com/spirituality/default.cfm?loadref=4

2 http:/ / carmelitanacollection.com/spirituality.php

SCRIPTA, Revista internacional de literatura i cultura medieval i moderna, núm. 7 / juny 2016 / pp. 132-149 ISSN: 2340-4841 · doi:10.7203/SCRIPTA.7.8473 
The Founding Mother had «emphasized women's capacity to practice self-discernment and their right to mystical pleasure...» (Weber 2009: 199), harping on the idea that religious poetry could inspire joy (Morris 1986: 244). As several scholars have noted, Discalced Carmelite women very often «had the necessary competence in poetic and allegorical codes...» (e. g., Weber 2009: 200). Gender played a pivotal role in self-representation within their poetic frame. In general, «Para poder expresar su humillación, su abnegación, su desnudez del alma, el escritor de lírica religiosa descubre los atributos femeninos de su ser y feminiza su discurso» (Olivares \& Boyce 2012: 23). Female poets, however, faced a different set of expectations: «El problema de la poeta en la poesía sacra era el de expresar su propia relación femenina con el objeto de su deseo, Dios, en un discurso poético ya feminizado» (Olivares \& Boyce 2012: 24). Thus, ensuring the insertion of a female poetic voice into an already-feminized discourse appropriated by male mystic poets such as St. John of the Cross, while at the same time re-working the relationship of soul and divinity, could pose a complex literary and spiritual conundrum.

Filtered through St. Teresa's maxim in Camino de perfección, «acostumbrarse a soledad es gran cosa para la oración» (chapter 4, meditation 9), ${ }^{3}$ reliance on the Carmelite trope of solitude offered one device for facilitating the path to mystical union. St. Teresa had written, for instance, «Muchas veces, Señor mío, considero que si con algo se puede sustentar el vivir sin Vos, es en la soledad, porque descansa el alma con su descanso, puesto que, como no se goza con entera libertad, muchas veces se dobla el tormento ... » («Exclamaciones» II, 1). In this dicho, the equation of solitude and rest (stated twice, as verb and then as noun) springs from freedom from what one may suppose are worldly duties. Awareness of obligations outside communion with the godhead and a yearning to return to that spiritual quest, due not only to living in community but also to leadership roles, pervades the writings of many early modern nun-poets.

The female Discalced Carmelite search for spiritual perfection through the trope of solitude emphasizes its spiritual, and more emphatically, its mystical benefits. ${ }^{4}$ The three Spanish poets whose work is studied here - María de San Alberto (1568-1640), Ana de la Trinidad (1577-1613), and Gregoria Francisca de Santa Teresa (1653-1736) — exemplify this tradition. The first two were contemporaries, of the generation immediately following the Saint's; Sor Gregoria was born fifteen to twenty years after their death, demonstrating that Discalced Carmelites continued to re-work the multi-faceted trope of solitude throughout the early modern period, exploiting and gendering the recurring themes and forms of the Order's poetic traditions. Consistently, they portrayed the benefits of solitude as a tool for forging spiritual perfection, especially as manifested in union with the divinity.

\footnotetext{
3 Teresa de Jesús, Camino de perfección (limovia.net, 2013), 40.

4 Although several critics have discussed the ambiguity of the term «mystic», here I understand it to refer to a state of seeking — and achieving — direct union with the divinity.
}

SCRIPTA, Revista internacional de literatura i cultura medieval i moderna, núm. 7 / juny 2016 / pp. 132-149 ISSN: 2340-4841 · doi:10.7203/SCRIPTA.7.8473 
While the poems considered here — «Liras a la soledad» by María de San Alberto, sonnets 7 and 4 by Ana de la Trinidad, and «La soledad del alma» by Gregoria Francisca de Santa Teresaare similarly framed in terms of content around solitude and its efficacy in facilitating spiritual, especially mystic states, they have each offer a different metrical form: lira, sonnet, and cuartetas with irregular rhyme. Notably, the earlier compositions belong to highly formal poetic systems, while the last clearly draws upon popular lyric. Despite the Founding Mother's use of popular meters, both Ana de la Trinidad and María de San Alberto evoked «high» culture in their choice of poetic genre, although their lexicon represented a more quotidian register. Perhaps a product of the cultural milieu in which both were educated, the lira and sonnets communicate an oral tone that softens the metrical rigidity.

\section{María de San Alberto}

María de San Alberto and Cecilia del Nacimiento separately and together produced an oewvre that followed two tendencies pioneered by St. Teresa, later continued by many: 1) accounts of and poetry dedicated to mystical experiences; and 2) occasional poems for a variety of celebrations, including the beatification and canonization of the Saint of Ávila. Despite recent examples of critical revindication, however, María de San Alberto has remained for the most part in her younger sister's literary and religious shadow. In his discussion of the female Teresian poetic tradition and Ana de la Trinidad's work, for instance, Jesús Fernando Cáseda Teresa mentions Cecilia del Nacimiento, but not María de San Alberto (1996: 88, n. 9). Although the poem discussed here, «Liras a la soledad», has twice been studied (Schlau 2009; Weber 2009), it merits further critical attention.

In the poem, Solitude is addressed as a beloved friend. As in Ana de la Trinidad's soneto 7, the poetic voice and the allegorical figure of the liras achieve some measure of equality through apostrophe («O soledad amiga»). The discourse inflected with an intimate tone, as well as the use of personification, «establish the importance of the addressee in facilitating the path to spiritual perfection, as well as the long acquaintance of the speaker with the uses of solitude» (Schlau, «María» 223). Solitude, an allegorical figure, «...becomes a high priestess, the queen who helps the aspirant to prepare the inn (the soul) for the arrival of the divine guest» (Schlau 2009: 222-23). In general, poetic devices and strategies, as well as sophisticated verse- making, reflect the writer's humanistic education and the influence of the Discalced Carmelite Order's greatest mystic poet, San Juan de la Cruz. Weber has argued, for instance, that María de San Alberto is adept at reproducing the monkpoet's «incantatory alliterations, his biblically inflected pleonasms, and ...delicately echoing rhymes» (2009: 195). The devices that Weber attributes to John of the Cross, however, may very well reflect the originality of the poet of the «Liras a la soledad».

Indeed, María de San Alberto's verses unerringly resonate with sounds of choral recitation by and 
with her audience of Sisters, the nuns of the Valladolid convent. ${ }^{5}$ Repetition of sounds (aposenta/ contenta and esposo/reposando), for example, intimates a significant connection between solitude and union with the divinity. The rhythm of the words also evokes comfort and safety, by expressing the sentiment mimetically (Schlau 2009: 223). Although Weber suggests that the poet allows «the parallel lines of lyric and allegory to intersect», and thus the «coherence of the fictive ' $\mathrm{I}$ ' is weakened» (2009: 195), I would argue that the speaker's voice emerges quite strongly. Indeed, it appears that through the personal relationship with a personified Solitude, the poetic voice defines itself as an independent entity, capable of carving its own path toward the spiritual goal of mystic union. Thus the goal of spiritual perfection is achieved by an autonomous religious subject, with the help of Solitude. The poem also serves a pedagogical purpose: for the audience of nuns, it offers a means of entering into a relationship that may possibly lead to greater spiritual and religious fulfillment.

Interestingly, the first lira begins with a gesture of deference, with the assertion of Solitude's absolute sovereignty («que de todo te muestras señora»), followed by the speaker's announced confusion and inarticulateness («no sé de ti qué diga»). Ironically, of course, the poem itself becomes an artifact that contradicts the inability to speak with its very existence. Not surprisingly, the stanzas that follow the declaration, «no sé de ti qué diga», elaborate Solitude's virtues, functions, and uses, as well as the aspirant's longing for her company (which is no companionship, of course). A central paradox is highlighted: Solitude serves as faithful companion in the lines, «Que tú eres compañía / al alma que de amor está sedienta». A perfect guide, the allegorical being addressed here offers a way out, through the memory of suffering, to «la eterna gloria» for both soul and herself.

Linguistically, this poem avails itself of a quotidian lexicon. The imagery as well depends on ordinary events. An energetic rhythm, evident in its verses, softens and lightens the liras. Despite the tight rhyme scheme and the careful rigidity of the poetic form that refer back to the poet's elite cultural background, mundane routines of daily life prevail in the poetic devices. An ordinary activity, travel, is, for instance, suggested in the metaphor of the inn. Overall, the verses suggest a dynamic account of the movement toward union, especially through the use of verbs that denote a wide variety of activities, with multiple subjects: mora, diga, goza, aposenta, subamos, esté velando, velar continuamente. Solitude thus provides a space in which the soul can maneuver at will. There is little passivity associated with the search for God as described in these lines.

The soul's desire to act, springing from the need to join with God, contrasts with the focus on Solitude's state of being: the supplicant comes to her, while she remains static, ever-present, but essentially a model as well as a guide on the path toward mystic union. Solitude, both a friend and a mentor, ultimately leads the aspirant to a sense of peace and tranquility that resonates with the sleep (akin to death) that the material body requires. Indeed, while that body lies in repose, the soul remains alert, waiting for the expected end, although the speaker accepts the inevitability of 5 Unlike her sister Cecilia del Nacimiento (who spent a decade in Calahorra), María de San Alberto remained in the
Convento de la Concepción in Valladolid from when she entered in 1587 until her death in 1640.

SCRIPTA, Revista internacional de literatura i cultura medieval i moderna, núm. 7 / juny 2016 / pp. 132-149 ISSN: 2340-4841 · doi:10.7203/SCRIPTA.7.8473 
temporal uncertainty: «no sé quando». Ultimately, resolution comes precisely because of the duality of body and soul; the two find themselves able to merge in the godhead. Solitude's companionship establishes the parameters that make possible the inevitable end of physical life, while at the same time anticipating an eternal existence united with the divine Bridegroom.

As convent leader, María de San Alberto had ensured the construction of a hermitage in the convent garden, to which members of the community might retreat for prayer and meditation. Clearly, she recognized the need to periodically withdraw from the daily rhythms of community life, since she herself spent a great deal of time engaged in the business of interacting with religious sisters, as well as with secular others from outside the convent walls, in her role as Mother Superior. And she wanted to facilitate her religious daughters' ability to engage with solitude in the pursuit of spiritual perfection. Thus, the physicality of Solitude, in the poem literally a «posada», evokes the actual space that Madre María created to aid the nuns in walking along that path. The last verses open the door to the divinity, the reward for perseverance in prayer and the effort of stripping away the layers of corporeality, in order that the soul merge with the Husband. True rest is only achieved in this way: «dándole tal morada / que con eternal gloria sea pagada». Solitude paves the way, just as St. Teresa had prescribed.

\section{Ana de la Trinidad}

Significantly, María de San Alberto's biological and religious sister, Cecilia del Nacimiento, was also Ana de la Trinidad's religious mother (and most probably poetic mentor). Madre Cecilia had been sent to the Calahorra convent from Valladolid in 1601, both because of internecine politics in the Order and also to aid in stabilizing the foundation, just three years after its establishment. Elected prioress twice during the approximately ten years she remained, Cecilia del Nacimiento also became Mistress of Novices during that time. Sor Ana professed in 1603; the timing is such that the nun from Valladolid undoubtedly instructed her. Even more importantly for literary history, it is literally because of Cecilia del Nacimiento that nineteen of Ana de la Trinidad's sonnets are extant. The Calahorran nun-poet had asked that all her writings be burned upon her death; only those poems survived that Sor Cecilia had previously transcribed and brought back to the Valladolid convent when she returned there. Thus, we owe to Cecilia del Nacimiento's actions present-day access to (at least some of) the poetry of Ana de la Trinidad.

Cecilia del Nacimiento's brief vida of Ana de la Trinidad notes her spiritual daughter's skill in «latinidad, aritmética y música», as well as her self-taught proficiency in painting and making things by hand. Strikingly, mention of these abilities resonates with, may very well be an (unconscious) allusion to her own biological mother, the renowned humanist Cecilia Morillas Sobrino (1539-1581), whose vida, authored by one of her sons, Diego de San José, highlighted almost identical skills. Not only does Sor Cecilia assert Sor Ana's high level of cultural literacy, but she also confirms her work 
as a poet. At the end of the account, she notes that, «Unos sonetos que ella me dio, que compuso en diferentes afectos del alma, para que se vea su buen espíritu, que es lo que me ha quedado suyo, van con este papel. Son de su letra, que la hacía muy buena...» (quoted in Álvarez 1992: 279). Although José María Díaz Cerón, the editor of Cecilia del Nacimiento’s 1971 Obras completas, had attributed the nineteen sonnets to the Valladolid poet, more recently critics have used Madre Cecilia's words to assert Ana de la Trinidad's authorship. ${ }^{6}$ Cecilia del Nacimiento had declared that Sor Ana received a humanistic education, which is partially substantiated in the younger woman's use of the sonnet form, relatively rare in the female Discalced Carmelite poetic tradition.

Although in terms of rhyme and meter, Ana de la Trinidad's poems do not follow the use of popular lyrical forms that predominate in the Founding Mother's verses, the sonnets nevertheless clearly reflect the themes and preoccupations outlined in St. Teresa's writings. Cáseda, for instance, insists on Sor Ana's «[c]onstante búsqueda de la soledad» (1996: 89), as well as the confessional tone of the poetry, product of a «rubor místico teresiano, un continuo ofrecerse en el poema en templanza lírica sostenida» (1996: 88). Suggestively, as a practitioner of the mystical paradigm outlined by the Saint of Ávila, the mystic lyricist poeticizes the ecstatic experience by drawing upon much the same thematic content and imagery as the first Discalced Carmelite nun-poet.

Nowhere is the Teresian influence more evident than in the sonnet that begins, «Solitaria quietud a do se anida / el alma con inmensa sed sedient» (Ana de la Trinidad 1998: soneto 7). Not only does line 4 echo Psalm 30, 3-4, but also lines 8 and 13 resonate with parts of St. Teresa's and St. John's writings. ${ }^{7}$ As Emeterio García Setién pointed out long ago, line 8 literally echoes St. Teresa's first Exclamación a Dios, which begins, «iOh vida, vida!, ¿cómo puedes sustentarte estando ausente de tu Vida? En tanta soledad, ¿`en qué te empleas?» In Sor Ana’s first two lines, solitude is imagined as a concrete structure, a physical space in which the thirsty soul dwells, and feels at home («anida»). The repetition of sound and meaning in «sed sedienta» highlights the yearning for God aided by a state of quietude, which is itself facilitated by being alone.

For Cáseda, Sor Ana's poetry reflects «all» the tropes of mystical literature: «el portus quietus, la noche, el alma peregrina, la soledad sonora, la llama encendida, el simbolismo de la salamandra, el vivir sin vivir en mí, el silvo vulnerado, el mar y el viento bíblicos, la barquilla, la mariposa y la llama, la selva oscura, la tórtola viuda ... (1996: 92). Notably, in the two sonnets discussed here, three of these motifs appear: the wandering soul, sonorous solitude, and the salamander. The particular focus on «soledad sonora» is evident in the first two lines of sonnet 7: «Solitaria quietud a do se

6 Díaz Cerón's edition of the Obras completas, while extremely useful, omits several of her works and misattributes others.

7 «El cuarto verso recoge el eco del salmo 30, 3-4 (Señor, sé mi roca de refugio . . . tú eres mi peña y mi alcázar). También los versos 8 y 13 parecen contener resonancias cercanas de pasajes de Santa Teresa y San Juan de la Cruz (cf. Exclamación 1,1; y Llama de amor viva estrofa 1)» (Álvarez, «19»). 
anida / el alma con inmensa sed sedienta». Also, the thirsty soul searches, attempting to find a place of rest. In addition, the desert, so prominent in Carmelite lore, is implicitly evoked (through wandering and thirst). Only when Solitude comes to the speaker's aid can she find inner peace; in sonnet 7 , only then can she be reborn as both a phoenix and a salamander.

In sonnet 4, solitude soothes the soul, even transforming «llanto en alegría». Antithesis and contrast play an important role, but other forms of imagery also predominate. Certainly, the path to spiritual fulfillment requires solitude's intervention: «Pues eres tú mi luz, mi guarda y guía». Surprisingly, in these verses the poetic voice manages to sound quite forceful and authoritative: repetition of the strong negative phrase «no quiero» emphasizes the speaker's purpose. Impatiently, she requires God to give her what she wants. The sonnet culminates in imagery of rebirth, the goal of the search for attainment of mystical union, through the simile of the phoenix in the first tercet and the metaphor of the salamander in the second. Both animal beings have been repeatedly been used as compelling symbols in Western mythology. One is purely mythical and the other, a specific animal, yet both remain reminders to the collective imagination of the power of life forces and belief. Further, both are associated with fire, and therefore evoke the «sol» in «soledad». The phoenix's rebirth from death as new and pure - it arises from its own ashes - may be viewed as a metaphor for Christ's resurrection. The salamander, a creature of water but linked in legend to fire, a nocturnal being connected to solar power, represents those who pass through the fires of passion in this world in purity and without stain: Jesus, Mary, and those who imitate them.

In her poetry, Ana de la Trinidad «recurre a la antítesis, la oposición y el contraste constantemente» (Cáseda 1996: 91). Both sonnets 4 and 7 reflect this stylistic feature. The poetic voice of sonnet 7 insists on the necessity of creating distance from and absence in the world, of «saying good-bye», in order to maintain a relationship with God. Uncomfortable in this world — «que vivo ausente de mi propia vida»— the soul directly addresses a personified Solitude. This figure has deep knowledge of the speaker's «ansias y fatigas»; she offers refuge, an escape from the alienation experienced by living life on earth: «en ti me esconde adonde no me sienta». Solitude has great power, insofar as she becomes vehicle for communicating with God; the speaker commands her to tell the deity to either stop being angry or to allow her to die: «que cesen sus enojos o me acabe».

Steeped in the Teresian mystic tradition, like St. John of the Cross and Fray Luis de León, Ana de Trinidad may also have been influenced by the Kabbalah (Acereda 1998: 59). He notes that there is, «una cierta identidad de contenidos y símbolos, una recurrencia de imágenes y metáforas, de léxico y clima poético...» (Acereda 1998: 63), but only hints at what those similarities might be. Study of these parallels would deviate from the topic of this paper, but it is worth noting that at least basic discussions of Kabbalistic concepts must have been available in Sor Ana's cultural environment. That there was an awareness of the existence of other mystical traditions, in this case a Jewish one, harks back to a form of convivencia not often attributed to early modern Catholic orthodoxy. Specifically, Ana de la Trinidad's poetry may 
Stacey Schlau. A Nest for the Soul: The Trope of Solitude in Three Early Modern Discalced Carmelite Nun-Poets

reflect some of these connections; hopefully, studies uncovering possible contacts will emerge in the near future.

In sum, Ana de la Trinidad's sonnets both fit neatly into, and somewhat diverge from the Teresian poetic tradition. They are the work of an accomplished poet, well-versed in elite literary culture, and the motifs and stylistic norms of Discalced Carmelite poetics. The poet's use of the trope of solitude undoubtedly follows, rather than diverges from the ideological tendencies of her Order. In that sense at least, she remains a spiritual and literary daughter of St. Teresa of Avila.

\section{Gregoria Francisca de Santa Teresa}

Sor Gregoria Francisca de Santa Teresa's life spanned the second half of the seventeenth century and the first decades of the eighteenth, a few generations after Ana de la Trinidad and María de San Alberto. Like the two earlier Discalced Carmelite poets, Sor Gregoria Francisca followed St. Teresa's model of combining activity to further the Order with contemplation and the search for spiritual perfection. Following her religious models, she not only became Mother Superior and Mistress of Novices, and founded a new convent, but also exercised her vocation for writing poetry. Having professed at a young age in the Seville convent founded by the woman whom Teresa de Jesús had called «mi letrera», María de San José [Salazar] (1548-1603), she too was imbued with the Carmelite literary tradition. When Diego de Torres Villarroel, author of her Vida (1738), asserted that she learned Latin through divine grace, a common claim among biographers of exemplary religious persons during the early modern period, he intended to prove her religious exemplarity. At the same time, though, he reinforced her entitlement to elite literary culture. In short, like María de San Alberto and Ana de la Trinidad, Gregoria Francisca de Santa Teresa exemplifies those of St. Teresa's daughters who emulated their Mother's literary and spiritual activities.

Belén Molina Huete has argued that without an understanding of the Carmelite mystical poetic tradition, Gregoria Francisca de Santa Teresa's poetry cannot be understood. She advocates an approach that takes into account the «contexto creativo de las composiciones y no de un a priori globalizador, lo que exige, como marco de trabajo, una más que necesaria reivindicación de la tradición mística y poética carmelitana en que se inserta la obra de esta religiosa» (2013: 1). Indeed, the nineteenth-century editor of Sor Gregoria's poetry calls her «la nueva Teresa» (Poesías 1865: 2). Even in her own time, her poetry was praised by «intelligent men», although convent superiors required that it be burned (Perry 1991: 75).

Sor Gregoria Francisca's poetry receives attention even in our time, and not only from literary and religious historians. A contemporary blogger, for instance, in addressing her work, writes about her the use of solitude as a theme, figure, or motif. He comments that her verses «posee[n] en los momentos más felices acentos propios y motivos de inspiración preferentes y característicos que configuran su personalidad: la soledad y el amor» (Arias Solís 2006). Thus, he underscores

SCRIPTA, Revista internacional de literatura $i$ cultura medieval i moderna, núm. 7 / juny 2016 / pp. 132-149 ISSN: $2340-4841 \cdot$ doi:10.7203/SCRIPTA.7.8473 
the connection between solitude and (divine) love in her work. Most notably, the blog widens the audience for her verses, including anyone who, surfing the internet, might read his words, in addition to those scholars of the early modern period interested in literary and religious history.

Sor Gregoria Francisca’s poem, «La soledad del alma», is not only chronologically the latest, but also the longest, of the four discussed here. Despite the commonality of verses with those of her predecessors, insofar as they describe the Carmelite path toward mystical union, the tone, language, and emphases of this poem differ dramatically from theirs. Most obviously, there is no direct relationship between the poetic voice and a personified Solitude. Rather, four-line stanzas recount, in discourse for the most part denuded of imagery and adornment, the tempestuous and contradictory feelings of a soul intent upon achieving union with the godhead. Sor Gregoria's poetry in general «provides some striking insights into a consciousness that linked together body and soul with a tension of shifting and paradoxical feelings» (Perry 1991: 73). In «La soledad del alma» in particular, she poeticizes the struggle to gain mystical union without emphatically expressing strong feelings. That is, there is a kind of detached quality to the poem, especially in the expression of poetic voice, that is not evident in either Ana de la Trinidad's or María de San Alberto's verses.

Beginning with Russell Sebold in the 1990s, most critics writing about Sor Gregoria have defined the nun-poet as fitting into the literary moment that Molina Huete has called «preneoclasismo». The term may be due to the authoring by renowned Neo-classical intellectual Diego de Torres Villarroel of the nun-poet's spiritual biography, published two years after she died. Or, it could be simply because of the historical period in which she lived, the early eighteenth century. What remains salient throughout Gregoria Francisca de Santa Teresa's extant poetic oeuvre, however, are an undoubted clarity of expression and an uncluttered style, in terms of both syntax and lexicon. The poems are highly accessible to most readers, despite the mystic themes and concerns they express. Possibly they represent the Neo-classical bent toward didacticism, the need to perceive literature as a means of educating readers.

Certainly, part of the tendency to clarity and simplicity resonates with St. Teresa's writings. In some ways, «La soledad del alma» comes closest of the four discussed here to the Founding Mother's colloquial style. The poetic voice here seems to want to communicate with the divine being directly and without flourishes. Sebold argues that this desire emanates from the desire for connection: «La mística Sor Gregoria ha llegado a la claridad por su afán de comunicación directa y sincera con el Amado» (1993: 138). Predictably, and similarly, in his Apuntes para una biblioteca de escritoras españolas, Manuel Serrano y Sanz cites and agrees with Marcelino Menéndez Pelayo when characterizing her poetry as the product of inspiration and religious fervor. Serrano y Sanz goes further than Sebold, insisting that Sor Gregoria is not a «poetisa culta» but «un corazón religioso que derrama sus afectos con mayor sencillez» (1905: II, 381). His well-intentioned, orthodox emphasis on religious aspects of the Sevillan Carmelite's poetry, however, has the effect of denigrating her literary worth.

SCRIPTA, Revista internacional de literatura i cultura medieval i moderna, núm. 7 / juny 2016 / pp. 132-149 ISSN: 2340-4841 · doi:10.7203/SCRIPTA.7.8473 
His cliché — the unlettered woman who nevertheless finds a way to express herself in poetryremained an integral part of much critical analysis of the literary works of Discalced Carmelite nun-poets until fairly recently.

Certainly, elements of the Teresian style such as use of popular meters and direct speech predominate in «La soledad del alma», as the author seeks to articulate her search for mystical union. The Calahorran writer constitutes an excellent example of Alvin Sherman's affirmation that, «A desire for personal and spiritual autonomy inspired others to emulate Santa Teresa's rhetorical style» (1996: 191). Still, the critical emphasis on simplicity should be viewed with caution, when considering Sor Gregoria's poetry —or St. Teresa's, for that matter — since the judgment obscures the (Discalced Carmelite) cultural milieu in which the two nun-poets lived and wrote, as well as the pedagogical nature of their verses.

The trope of solitude functions quite differently in «Soledad del alma» than in the previously discussed poems. Neither directly addressed nor personified, the poetic emphasis on solitude as a friend or necessary companion for spiritual solace does not become clear until the last stanzas. In the first section, the poetic voice articulates a sense of emptiness, of deprivation. The recurring use of words such as «yerma» (barren) and «desierta» (empty) emphatically draws the reader's attention to inevitable periods of spiritual drought (about which St. Teresa wrote so eloquently), rather than the fulfillment of mystic desire.

Focusing on a process of inner exploration, the poem insists on a contradictory set of feelings and sensations that leads to mental paralysis. Throughout, Sor Gregoria repeatedly contrasts physical and spiritual worlds (Sherman 1996: 196). One after another, abilities become absorbed, the senses confused, and the «loca» imagination wants to free itself, but cannot find a foothold. In short, the poetic voice struggles to find her way, as we see in this enigmatic stanza:

\footnotetext{
Confusos los sentidos,

No acaban de perderse,

Porque su mismo susto

Los pasma, y los detiene.
}

The speaker, although disoriented, does not totally lose her sense of place; nevertheless, fear itself causes fear, and thus impedes movement. When the soul manages to rise, the body fails: all energy and strength are dedicated to the spiritual quest. Alone, always alone, the soul struggles, unsure of what is happening, but experiencing «Un no se qué Divino,/Que la tiene y mantiene./ En soledad muy suma/De todo lo terrestre». Here the soul's solitude is constituted by separation from mundane affairs, the need to be alone and silent, in order to be open to faith and love of and for the divinity. Although in other poems Sor Gregoria uses martial language to urge the soul to stand against the Devil, «describing her inner state as one of conflict and struggle» (Perry 1991: 
76), in «Soledad del alma» a sense of peace accompanies the interior conflict and quest for unity with God. Love propels the speaker to unite with «su Amante», a union to which she aspires and which she ardently desires.

Just before the end, the poet echoes St. Teresa's juxtaposition of living and dying, with a series of antitheses and paradoxes: «desierta vive» is contrasted with "penando muere», the emphasis on suffering as process expressed through the gerund, while the essential aloneness of life is expressed in «desierta». These lines are following by an alliterative play on understanding and knowing: «Sin saber de sí misma/sin entender entiende». In both lines, knowing is not knowing, understanding is not understanding, thus situating the reader (along with the poetic voice) in that space and time where the mind and body let go, in order to embrace the divinity. An apparently contradictory (mental) emptiness permits the approach to the divinity.

The poem's final stanza returns to a direct celebration of solitude:

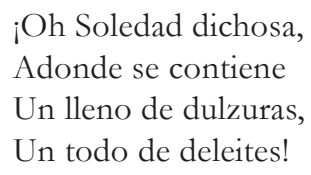

Here Solitude is a proper noun, an entity unto itself. The poem culminates in a joyous acknowledgement of the gifts that solitude brings: «un lleno de dulzuras, / Un todo de deleites!». As a reward for its perseverance and adherence to the quest for union, the solitude of the soul becomes precisely that which the speaker desires: the ultimate merging — with God.

Mary Elizabeth Perry defines Gregoria Francisca de Santa Teresa's poetry as an act of «passionate subversion» (1991: 78), arguing that the mystic poet rejects the traditional dichotomy of body and soul. That may be, but the depiction in «La soledad del alma» of the struggle to find a place in the spiritual universe of mystic unity, grounded in the tenets and language of early modern Spanish Catholic discourse and dogma, most obviously finds resolution precisely in rejecting earthly, material matters and accepting an empty (interior) space in which the soul attains peace. St. Teresa's call to seek that place is answered in Sor Gregoria's poem.

The three poets discussed in this essay explore the possibilities of creating and maintaining solitude while embarked on a quest for mystical union. In their verses, they express the trials and contradictions of the way of perfection. Addressing a personified Solitude or singing her praises, each speaker celebrates the potential inherent in claiming a material as well as spiritual space, not for personal autonomy but rather for that kind of wholeness found in communion with the divinity. Their verses document the difficulties, but also the beauty and ultimate fulfillment of the path they followed. Outstanding poets of the Teresian tradition, the Founding Mother's religious and literary example allowed María de San Alberto, Ana de la Trinidad, and Francisca Gregoria de Santa Teresa the freedom to communicate with their religious sisters and subsequent readers, poeticize the path toward mystical union, and ultimately to establish religious community through writing. 
Stacey Schlau. A Nest for the Soul: The Trope of Solitude in Three Early Modern Discalced Carmelite Nun-Poets

\section{Bibliografía}

Acereda, Alberto (1998) «Expresión poética y anhelo divino en Ana de la Trinidad»,_Kalakorikos, no. $3,59-71$.

Álvarez Fernández, Tomás (1992) Poetisa, riojana y carmelita: Ana de la Trinidad, Burgos: Monte Carmelo.

Ana de la Trinidad (1998) 19 sonetos de una poetisa desconocida. La Carmelita Ana de la Trinidad del Carmelo de Calahorra, ed. Tomás Álvarez, Burgos: Monte Carmelo.

—. Soneto 4, http://www.abandono.com/rincones/oraciones/cien-sonetos-para-el-senor/.

Arias Solís, Francisco (2006), «La voz de la mística sevillana», http://franciscoarias.blogcindario. com/2006/10/00269-sor-gregoria-francisca-de-santa-teresa-por-francisco-arias-solis.html.

«Carmelite Spirituality» (n. d.) http://www.carmelite.com/spirituality/default.cfm?loadref=4.

«Carmelite Spirituality and History» (n. d.) http://carmelitanacollection.com/spirituality.php.

Cáseda Teresa, Jesús Fernando (1996), «La poesía mística de sor Ana de la Trinidad», Kalakorikos, no. $1,85-93$.

De la Croix, Paul, OCD (n. d.) «Carmelite Spirituality», https://www.ewtn.com/library/SPIRIT/ CARMSPIR.TXT.

Díaz Cerón, José María, ed. (1971), Obras completas de Cecilia del Nacimiento, Madrid: Editorial de la Espiritualidad.

María de san Alberto (1999) «Liras a la soledad», Viva al siglo, muerta al mundo: Obras escogidas de María de san Alberto (1568-1640), ed. Stacey Schlau, New Orleans: University Press of the South, 22526.

Molina Huete, Belén (2013) «Preneoclasicismo y mística: La poesía de sor Gregoria Francisca de Santa Teresa», http://riuma.uma.es/xmlui/bitstream/handle/10630/6330/Nueva_versi $\% \mathrm{C} 3 \% \mathrm{~B} 3 \mathrm{n}$ Molina Huete Gregoria.pdf? sequence $=6$.

Morris, C. Brian (1986) «The Poetry of Santa Teresa», Hispania, Vol. 69, no. 2, 244-50.

Olivares, Julián, ed, (2009) Studies on Women's Poetry of the Golden Age: Tras el espejo la musa escribe, Suffolk UK and Rochester NY: Tamesis.

Olivares, Julián and Elizabeth Boyce (2012), «Introducción», in Tras el espejo la musa escribe. Lirica femenina de los Siglos de oro, eds. Julián Olivares and Elizabeth Boyce, 2nd edition, Madrid: Siglo XXI, 15-94.

Perry, Mary Elizabeth (1991), «María de San José, Ana de Jesús, and Gregoria Francisca de Santa Teresa: Subversion and Seduction: Perception of the Body in Writings of Religious Women in Counter Reformational Spain», in Religion, Body and Gender in Early Modern Spain, ed. Alain Saint-

SCRIPTA, Revista internacional de literatura i cultura medieval i moderna, núm. 7 / juny 2016 / pp. 132-149 
Stacey Schlau. A Nest for the Soul: The Trope of Solitude in Three Early Modern Discalced Carmelite Nun-Poets

Saens, San Francisco: Mellen Research University Press, 66-78.

Poesías de la Venerable Madre Gregoria Francisca de santa Teresa, carmelita descalza en el convento de Sevilla, en el siglo doña Gregoria Francisca de la Parra Queinoge (1865), Paris: Librería de Garnier Hermanos, 5357. https://books.google.com/books?id=DY6KXcxX6NMC\&pg $=P P 13 \& l p g=P P 13 \& d q=G$ regoria + Francisca + de + Santa + Teresa\&source $=$ bl\&ots $=t$ JVImuKctO\&sig $=5 \mathrm{M} 8 \mathrm{DkpAcbD} 3-$ DA8XiW2L49150tI\&hl=en\&sa=X\&ved=0CGEQ6AEwDWoVChMIk6T81PCPxgIVwZ6AC

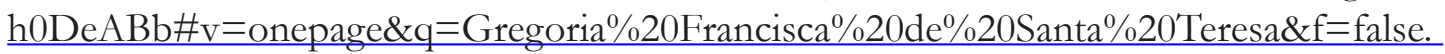

Schlau, Stacey (2009) «María de San Alberto: Bridging Popular and 'High' Spanish Poetic Traditions Through the Sacred», in Studies on Women's Poetry of the Golden Age: Tras el espejo la musa escribe, ed. Julián Olivares, Suffolk UK and Rochester NY: Tamesis, 218-32.

ed. (1999), Viva al siglo, muerta al mundo: Obras escogidas de María de san Alberto (1568-1640), New Orleans: University Press of the South.

Sebold, Russell J. (1993), «Entre siglos: Barroquismo y neoclasicismo», Dieciocho, Vol. 16, no. 1-2, $131-48$.

Serrano y Sanz, Manuel (1905), Apuntes para una biblioteca de escritoras españolas del año 1401 al 1833, 2 vols., Madrid: Sucesores de Rivadeneyra.

Sherman, Jr., Alvin F. (1996), «The Lover and the Captive: Sor Gregoria Francisca de Santa Teresa's Mystical Search for the Feminine Self in 'El pajarillo'», Dieciocho: Hispanic Enlightenment, Vol. 19, no. 2, 191-201.

Teresa de Jesús (2013) Camino de perfección, limovia.net.

Weber, Alison (2009) «Could Women Write Mystical Poetry?: The Literary Daughters of Juan de la Cruz», in Studies on Women's Poetry of the Golden Age: Tras el espejo la musa escribe, ed. Julián Olivares, Suffolk UK and Rochester NY: Tamesis, 185-201. 
Stacey Schlau. A Nest for the Soul: The Trope of Solitude in Three Early Modern Discalced Carmelite Nun-Poets

\section{Appendix: Poems}

María de san Alberto (1568-1640)

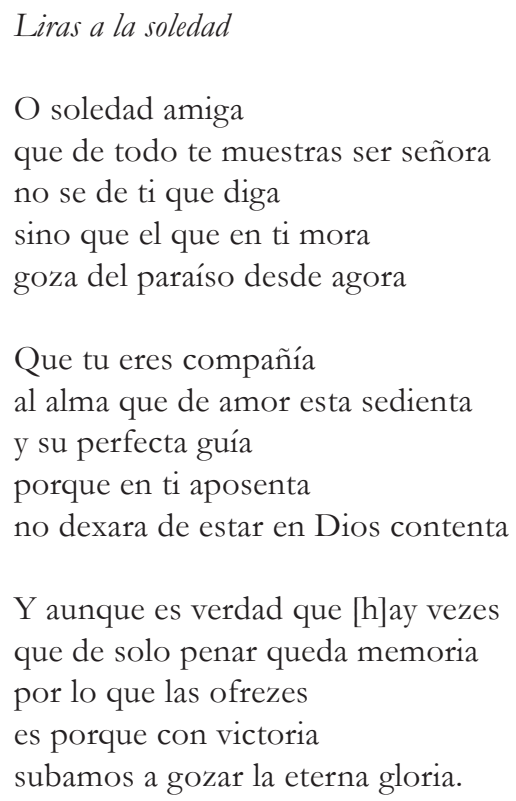

Que tu eres compañía

al alma que de amor esta sedienta

y su perfecta guía

porque en ti aposenta

no dexara de estar en Dios contenta

$\mathrm{Y}$ aunque es verdad que [h] ay vezes que de solo penar queda memoria por lo que las ofrezes

es porque con victoria

subamos a gozar la eterna gloria.

En ti deseo verme

para vivir en esposo reposando por que si el cuerpo duerme

el alma este velando

pues tengo de morir y no se quando

Aqueste es buen reposo

velar continuamente en tu posada

por venir al esposo

dándole tal morada

que con eterna gloria sea pagada. 
Stacey Schlau. A Nest for the Soul: The Trope of Solitude in Three Early Modern Discalced Carmelite Nun-Poets

Ana de la Trinidad (1577-1633)

Soneto 7

Solitaria quietud a do se anida

el alma con inmensa sed sedienta, que no cabe en el mundo ni se asienta sino en estar de todo despedida.

Tú eres mi refugio, mi manida; en ti me esconde adonde no me sienta, joh soledad amiga!, y tú me alienta, que vivo ausente de mi propia vida.

Pues sabes bien mis ansias y fatigas, favoréceme en mal tan fuerte y grave, Mostrándote propicia y amorosa,

para que de mi parte a Dios le digas que cesen sus enojos o me acabe, que no puedo vivir en otra cosa. Soneto 4

¡Oh peregrino bien del alma mía que solo, sin resabios ni recelos puedes matar mi sed, quitar mis duelos y convertir mi llanto en alegría!

Pues eres tú mi luz, mi guarda y guía que tengo yo en la tierra y en los cielos, no quiero medios, no quiero consuelos, fuera de ti, de todo me desvía.

En soledad, de todo enajenada, desnuda de mi ser y de mi vida, para ser como fénix renovada,

en tu amorosa llama y encendida me arrojo, que si fuere allí quemada, seré cual salamandria renacida. 
Stacey Schlau. A Nest for the Soul: The Trope of Solitude in Three Early Modern Discalced Carmelite Nun-Poets

\section{Gregoria Francisca de Santa Teresa (1653-1736)}

\section{La soledad del alma}

Despúeblese mi alma, mis potencias me dejen, En una vida yerma, que no discurre ni siente.

Así se lamentaba, Triste en su adversa suerte, Un discreto; y yo trovo, Así sus caracteres.

Parece que mi alma Se halla muchas veces Tan desierta que á sí Aun no puede entenderse.

Las potencias absortas, Que ni moverse pueden Para sus actos propios De un ay están pendientes.

Confusos los sentidos, No acaban de perderse, Porque su mismo susto Los pasma, y los detiene.

La imaginación loca Tal vez soltarse quiere; Pero no encuentra estribo, Adonde sostenerse.

Sube sobre sí el alma, Y el cuerpo desfallece, Que arrebata las fuerzas El superior ambiente.

Y aunque ella no discurre No conoce que siente Un no se qué Divino, Que la tiene y mantiene.

En soledad muy suma De todo lo terrestre, Con una inspiración Tan firme como leve: 
Stacey Schlau. A Nest for the Soul: The Trope of Solitude in Three Early Modern Discalced Carmelite Nun-Poets

Pues apenas percibe

El empleo que tiene,

Y como solitaria,

Se sienta y enmudece.

Suspensa y sin aliento,

Vive de lo que cree,

Siendo su fe el caudillo

Que conducirla puede.

Al dulce, amante empleo

Del amor que la mueve

A unirse con su Amante,

Aspira y apetece.

Así desierta vive,

Así penando muere,

Sin saber de sí misma,

Sin entender entiende.

Gustosa en sus pesares,

En nada gusto tiene,

Solo la gloria busca,

Del que es todos sus bienes.

¡O Soledad dichosa,

Adonde se contiene

Un lleno de dulzuras,

Un todo de deleites! 